\title{
Extraction of Chymotrypsin from Red Perch (Sebastes marinus) Intestine Using Reverse Micelles: Optimization of the Backward Extraction Step
}

\author{
Liang Zhou, Suzanne M. Budge, Abdel E. Ghaly*, Marianne S. Brooks and Deepika Dave
}

Process Engineering and Applied Science Department, Faculty of Engineering, Dalhousie University, Halifax, Nova Scotia, Canada

\begin{abstract}
Fish processing waste can be used to produce valuable by-products such as chymotrypsin which has applications in the food, leather, chemical and clinical industries. In this study, a reverse micelles system of AOT/isooctane was used to extract chymotrypsin from crude aqueous extract of red perch intestine. The effects of $\mathrm{pH}$ and $\mathrm{KCl}$ concentration of the backward extraction step on the total volume (TV), volume ratio (VR), total activity (TA), enzyme activity $\left(A_{E}\right)$, specific activity (SA), purification fold (PF), protein concentration (Cp) and recovery yield (RY) were studied. Changing the $\mathrm{pH}$ from 6.5 to 8.5 and the $\mathrm{KCl}$ concentration from 0.5 to $2.0 \mathrm{M}$ during the backward extraction step had no effects on the TV or VR. Increasing the pH from 6.5 to 7.5 increased $A_{E}, S A, C p, P F$ and RY by up to $47.06 \%, 30.0 \%$, $27.0 \%, 26.9 \%$ and $18.47 \%$, respectively but they all then declined with further increases in the $\mathrm{pH}$. Similar trends were observed when the $\mathrm{KCl}$ concentration was increased from 0.5 to $1.5 \mathrm{M}$. The decreases in these parameters were due to the denaturation of protein under high $\mathrm{pH}$. The highest $\mathrm{A}_{\mathrm{E}} \mathrm{Cp}$ and $\mathrm{RY}$ were achieved with $\mathrm{pH} 7.5$ and $1.0 \mathrm{M} \mathrm{KCl}$ concentration while the highest SA and PF were achieved with $\mathrm{pH} 7.5$ and $1.5 \mathrm{M} \mathrm{KCl}$ concentration. Addition of isobutyl alcohol in the backward extraction step increased the TV, $A_{E}$, TA, Cp, SA, PF and RY by $13.6 \%, 336.4 \%, 342.6 \%$, $81.1 \%, 146.4 \%, 146.2 \%$ and $345.8 \%$, respectively. Alcohol reduced the interfacial resistance for the reverse micelles and, thus, destroyed the reverse micelles structure. The values of $A_{E}, T A, S A, P F$ and RY obtained with reverse micelles methods were much higher $(2.3$ fold $)$ than those obtained with the ammonium sulphate method.
\end{abstract}

Keywords: Fish waste; Chymotrypsin; Extraction; Purification; Ultrafiltration; Fractionation; Microemulsions; Enzyme activity; Protein concentration; Recovery yield

\section{Introduction}

Currently, fish waste is an approved substance for disposal at sea and the Canadian fish industry is dumping all fish waste into the sea because there is no economical way of utilizing the waste off shore and it is costly to transport the large amount of fish waste to meal plants or land-based waste disposal systems [1,2]. The decomposition of large volumes of wastes lowers the level of dissolved oxygen in the water and generates toxic by-products $[3,4]$. However, fish waste is a valuable resource and can be used to produce value added products such as docosahexaenoic acid (DHA) and eicosapentaenoic acid (EPA), enzymes (pepsin, trypsin, chymotrypsin), collagen and oil [5-7].

Chymotrypsin has wide applications in food, leather processing, chemical and clinical industries. Industrially, chymotrypsin is produced from fresh cattle or swine pancreas and is commonly made in either a tablet form for oral consumption or as a liquid for injection. The price of chymotrypsin is related to the cost of raw material and the purity of the products. Using fish waste, rather than fresh cattle or swine pancreas, could dramatically lower the cost of chymotrypsin production. Chymotrypsin can be extracted from fish waste using a reverse micelles method. Reverse micelles are thermodynamically stable molecules that can extract large biomolecules like proteins through electrostatic interaction that attracts soluble proteins into the inner layer of the reverse micelles [8,9]. They form amphiphilic structures in polar organic media which can be used to extract large amounts of proteins in the aqueous phase without denaturation.

The reverse micelles extraction process is divided into two steps: forward extraction and back extraction. During the forward extraction step, the aqueous and organic phases are separately prepared and homogenized. After transfer of protein from the aqueous phase to the organic phase, the phases are separated by centrifugation and the protein is measured [8-10]. In the forward extraction step, selection of sur- factants and $\mathrm{pH}$ play significant roles in protein stabilization. Sodium di-2-ethylhexyl sulfosuccinate (AOT) is the most common surfactant used in chymotrypsin purification [8-11]. $\mathrm{pH}$ influences ionic molecular interactions in solution and therefore, influences the efficiency of extraction by reverse micelles $[8,10]$. In the backward extraction step, protein is transferred from reverse micelles to the aqueous solutions. This step is usually very slow and salt is added into the aqueous phase to assist the process [9]. However, increasing chloride ion concentration will decrease chymotrypsin yield by competing with chymotrypsin in the extraction process and the effect is particularly significant at low ionic strength $[8,11]$. According to Goto et al. [12] and $\mathrm{Hu}$ and Gulari [9], the limitations of the backward extraction step are due to the difficulty in separating proteins from AOT reverse micellar phase and the excessive time involved in the process.

\section{Objectives}

The aim of this study was to optimize the backward extraction step of the reverse micelles method while purifying chymotrypsin from fish processing waste. The specific objectives were: (a) to study the effect of $\mathrm{pH}(6.5,7.0,7.5,8.0$ and 8.5) and salt concentration $(0.5,1.0,1.5$ and $2.0 \mathrm{M}$ ) and alcohol addition in the backward extraction step of the reverse micelles method on the enzyme activity $\left(A_{\mathrm{E}}\right)$, protein concentration $(\mathrm{Cp})$, specific activity (SA), purification fold $(\mathrm{PF})$ and recov-

*Corresponding author: Abdel E Ghaly, Professor, Department of Process Engineering and Applied Science, Dalhousie University, Halifax, Nova Scotia, Canada, Tel: (902) 494-6014; E-mail: abdel.ghaly@dal.ca

Received March 07, 2012; Accepted April 11, 2012; Published April 13, 2012

Citation: Zhou L, Budge SM, Ghaly AE, Brooks MS, Dave D (2012) Extraction of Chymotrypsin from Red Perch (Sebastes marinus) Intestine Using Reverse Micelles: Optimization of the Backward Extraction Step. J Bioprocess Biotechniq 2:120 doi: 10.4172/2155-9821.1000120

Copyright: (C) 2012 Zhou L, et al. This is an open-access article distributed unde the terms of the Creative Commons Attribution License, which permits unrestricted use, distribution, and reproduction in any medium, provided the original author and source are credited. 
ery yield (RY)and (b) compare the effectiveness of the reverse micelles method to that of the ammonium sulphate precipitation method.

\section{Materials and Methods}

\section{Chemicals and reagents}

Tris, $\mathrm{HCl}, \mathrm{CaCl}_{2}, \mathrm{NaCl}$, ammonium sulphate, N-benzoyl-L-tyrosine ethyl ester (BTEE) and the release, methyl alcohol and n-butyl alcohol were obtained from Sigma-Aldrich, Oakville, Ontario, Canada. AOT, isooctane (2,2,4-trimethylpentane), chymotrypsin, isobutyl alcohol and BSA (bovine serum albumin) were obtained from Fisher scientific, Ottawa, Ontario, Canada. Reagents used included $0.05 \mathrm{M}$ Tris- $\mathrm{HCl}$ buffer $\left(0.01 \mathrm{M} \mathrm{CaCl}_{2}, \mathrm{pH} 7.5\right), 15 \% \mathrm{v} / \mathrm{v}$ isobutyl alcohol, 10 $\mu \mathrm{M}$ BTEE.

\section{Sample collection and preparation}

The fish, red perch (Sebastes marinus), used in the experiment were collected from Clearwater Seafood's Ltd., Halifax, Nova Scotia, Canada. The intestines were separated from fish, washed with cold water and isotonic saline solution to remove the blood in the tissue according to the procedure described by Chong et al. [13] and Boeris et al. [14]. The fish intestine was chopped into small pieces $\left(1 \mathrm{~cm}^{3}\right)$, weighed, marked and stored at $-20^{\circ} \mathrm{C}$

\section{Experimental design}

Tables 1 and 2 show the experimental parameters investigated in this study and their levels. In the forward step $\mathrm{pH}$ of 8.0 and $\mathrm{KCl}$ concentration of $1.5 \mathrm{M}$ was applied [10]. In the backward extraction step, the effect of $\mathrm{pH}(6.5,7.0,7.5,8.0$ and 8.5$)$ and four $\mathrm{KCl}$ concentration

\begin{tabular}{|l|l|}
\hline Factors & Parameters \\
\hline Forward Extraction & \\
\hline AOT & $20 \mathrm{mM}$ \\
\hline $\mathrm{pH}$ & 7.0 \\
\hline Time & $30 \mathrm{~min}$ \\
\hline Temperature & $4^{\circ} \mathrm{C}$ \\
\hline Backward Extraction & \\
\hline Salt concentration & $0.5,1.0,1.5$ and $2 \mathrm{M}$ \\
\hline pH & $6.5,7.0,7.5,8.0,8.5$ \\
\hline Time & $1 \mathrm{hr}$ \\
\hline Temperature & $4^{\circ} \mathrm{C}$ \\
\hline
\end{tabular}

No. of replicates $=3$

No. of runs $=60$

Table 1: Optimization of the backward extraction (changing $\mathrm{pH}$ and $\mathrm{KCl}$ concentration).

\begin{tabular}{|l|l|}
\hline Factors & Parameters \\
\hline Forward Extraction & \\
\hline AOT & $20 \mathrm{mM}$ \\
\hline $\mathrm{pH}$ & 7.0 \\
\hline Time & $30 \mathrm{~min}$ \\
\hline Temperature & $4^{\circ} \mathrm{C}$ \\
\hline Backward Extraction & \\
\hline Salt concentration & Optimum \\
\hline pH & Optimum \\
\hline Isobutyl alcohol & $15 \% \mathrm{v} / \mathrm{v}$ alcohol or $15 \% \mathrm{v} / \mathrm{v}$ distilled water \\
\hline Time & $1 \mathrm{hr}$ \\
\hline Temperature & $4^{\circ} \mathrm{C}$ \\
\hline
\end{tabular}

No. of replicates $=3$

Total no. of runs $=6$

Table 2: Effect of alcohol addition during backward extraction.
$(0.5,1,1.5$ and $2 \mathrm{M})$ were studied. After optimization of the backward step, the effect of alcohol addition ( $15 \% \mathrm{v} / \mathrm{v})$ on chymotrypsin recovery yield was studied. Finally, both the reverse micelles extraction method and the ammonium sulphate extraction method were compared on the basis of enzyme activity, specific activity purification fold and recovery yield.

\section{Crude enzyme extraction}

The extraction procedure (Figure 1) described by Heu et al. [15] and Castillo-Yáñeza et al. [16] was followed. The prepared frozen samples were thawed at $4^{\circ} \mathrm{C}$ overnight. A $50 \mathrm{~g}$ (wet basis) sample of fish gut was mixed with $150 \mathrm{~mL}$ isotonic saline solution and homogenized using a laboratory homogenizer (Polytron PT1035, Brinkmann Instruments, Toronto, Ontario, Canada) for $5 \mathrm{~min}$, then incubated for $8 \mathrm{hr}$ at $4^{\circ} \mathrm{C}$ to activate the chymotrypsinogen in the samples. After incubation, the sample was centrifuged at $20,000 \mathrm{~g}$ at $4^{\circ} \mathrm{C}$ for $30 \mathrm{~min}$ (MP4R, International Equipment Company, Needham, Massachusetts), then filtered and defatted with $50 \mathrm{~mL} \mathrm{CCl}_{4}$. The supernatant was considered a crude enzyme extract. The volume at each step was measured and the activity and concentration of crude enzyme were determined.

\section{Ammonium sulphate extraction}

The procedure (Figure 1) described by Kunitz [17] was followed. Ammonium sulphate was slowly added to the crude extract to reach $35 \%$ saturation with continuous stirring. The mixture was stirred for a further 30 minutes at $4^{\circ} \mathrm{C}$ and then centrifuged at 20,000 g for 15 min (MP4R, International Equipment Company, Needham, Massachusetts). The supernatant was collected and the saturation was then adjusted to $70 \%$ by addition of ammonium sulphate. After $30 \mathrm{~min}$, the suspension was centrifuged at 20,000 g for $15 \mathrm{~min}$. The pellets collected from the $35 \%$ and $70 \%$ saturation steps contained precipitated enzymes. Dialysis was performed on the pellets using Tris- $\mathrm{HCl}$ buffer. The enzyme concentration, activity and yield were then determined.

\section{Reverse micelles extraction}

The process of extracting chymotrypsin from fish waste by the reverse micelles method is shown in Figure 1. The forward extraction step was carried out usingan AOT concentration of $20 \mathrm{mM}$ and at a $\mathrm{pH}$ of 7.0. In the forward extraction step, crude enzyme was mixed with AOT organic solution and stirring at $300 \mathrm{rpm}$ using magnetic stirrer for 30 minutes and then separating the two phases by centrifugation. Aqueous solutions containing different $\mathrm{KCl}$ concentrations $(0.5,1,1.5$ and $2 \mathrm{M}$ ) were prepared. Tris buffer was used as a stripping solution in the backward transfer and the $\mathrm{pH}$ of the solution was adjusted to 6.5, 7.0, $7.5,8.0$ or 8.5 as recommended by $\mathrm{Hu}$ and Gulari [9]. Equal volumes of aqueous solution and organic solution were mixed in the tube and $15 \%$ $\mathrm{v} / \mathrm{v}$ isobutyl alcohol was added to the reversed micelles phase. Then the two phase systems were mixed for one hour in a beaker placed on a magnetic stirrer (Canlab NO. S8290, Atlanta GA, Georgia, USA). The mixture was then centrifuged for $15 \mathrm{~min}$ at $4000 \mathrm{rpm}$ (MP4R, International Equipment Company, Needham, Massachusetts) in order to separate into two phases $[9,12]$. The enzyme activity and yield were determined. During the backward extraction step the salt concentration and $\mathrm{pH}$ were changed and the same procedure was followed.

\section{Effect of alcohol}

After the optimal conditions for the backward extraction were determined, the effect of alcohol addition was studied. Distilled water was used as a control. The same volumes $(1.5 \mathrm{~mL})$ of distilled water and isobutyl alcohol were added to the aqueous phase during backward extraction. 


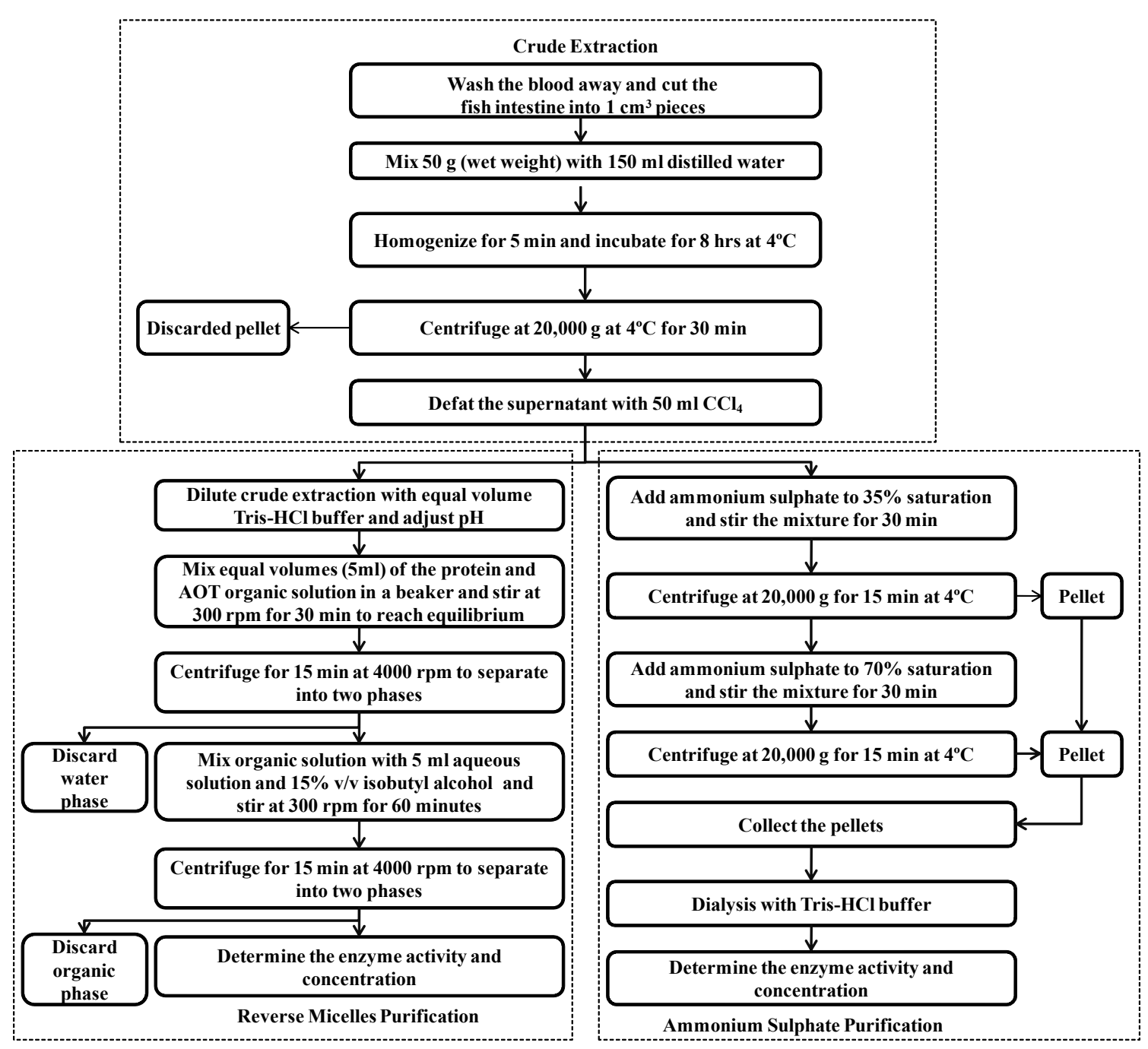

Figure 1: The extraction procedure of chymotrypsin from fish waste.

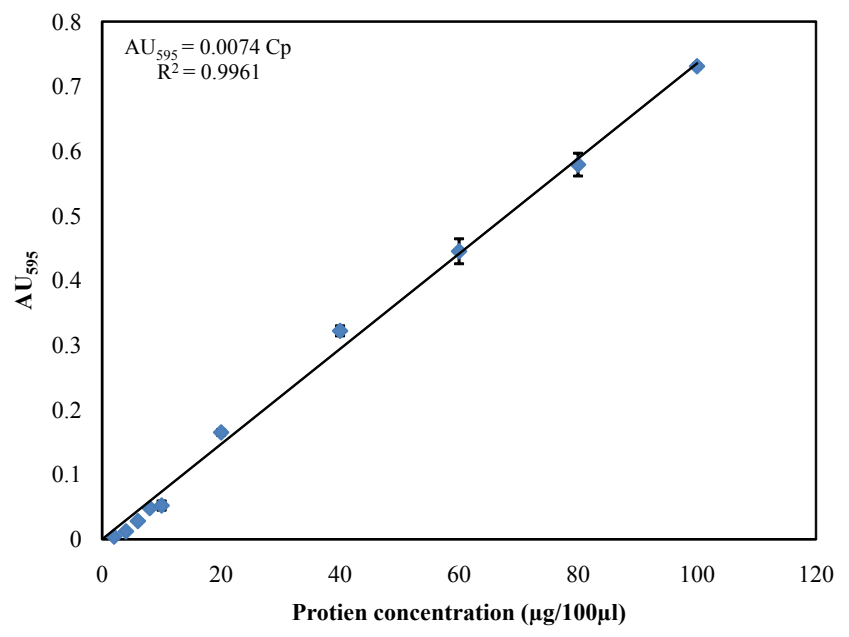

Figure 2: The standard curve for protein concentration.

\section{Determination of protein concentration}

The Bradford method was used for the determination of protein concentration according to the procedures described by Yang et al. [18] and Castillo-Yáñeza et al. [16]. Two standard curves were developed using a series of concentrations of bovine serum albumin (BSA): the standard curve (assay range 10-150 $\mu \mathrm{g} / \mathrm{mL}$ ) and a micro standard curve (assay range 1-10 $\mu \mathrm{g} / \mathrm{mL}$ ). The following solutions were prepared: (a) $0.1 \mathrm{~g}$ of BSA was dissolved in $10 \mathrm{~mL}$ of Tris- $\mathrm{HCl}$ buffer at room temperature (b) the stock BSA solution was diluted to span the $100-1,500$ $\mu \mathrm{g} / \mathrm{mL}$ range and (c) BSA solution in the range of $100-900 \mathrm{~g} / \mathrm{mL}$ was diluted ten times more for the micro standard curve. The two standard curves are combined together as shown in Figure 2.

$10 \mu \mathrm{L}$ of each standard was mixed with $5 \mathrm{~mL}$ of Bradford reagent. Each sample was allowed to incubate at room temperature for 10 minutes and the absorbance of each standard was measured at 595 $\mathrm{nm}$ against a blank that was composed of $10 \mu \mathrm{L}$ of buffer and $5 \mathrm{~mL}$ of Bradford reagent. $0.1 \mathrm{~mL}$ diluted sample (concentration between 5 to $100 \mu \mathrm{g} / \mathrm{L}$ ) was mixed with $5 \mathrm{~mL}$ Bradford reagent, incubated for 5 
Citation: Zhou L, Budge SM, Ghaly AE, Brooks MS, Dave D (2012) Extraction of Chymotrypsin from Red Perch (Sebastes marinus) Intestine Using Reverse Micelles: Optimization of the Backward Extraction Step. J Bioprocess Biotechniq 2:120 doi: 10.4172/2155-9821.1000120

Page 4 of 9

min and then the absorbance was measured at $595 \mathrm{~nm}$ [19]. The result was compared with the standard curve to determine the sample protein concentration.

\section{Determination of enzyme activity}

The activity of chymotrypsin was defined as the change of absorbance measured at $256 \mathrm{~nm}$ in one minute caused by the addition of 1 $\mathrm{mL}$ of chymotrypsin protein solution [20]. The substrate used in the experiment was benzoyl- tyrosine ethyl ester (BTEE). The p-nitroaniline was cleaved by BTEE and the release of N-benzoyl-L-tyrosine was followed by recording the increase in the absorbance every min for 5 $\mathrm{min}$ at $256 \mathrm{~nm}$ [13]. $1.5 \mathrm{~mL}$ Tris- $\mathrm{HCl}$ buffer $(0.08 \mathrm{M}$ tris, $\mathrm{pH} 7.8,0.1 \mathrm{M}$ $\left.\mathrm{CaCl}_{2}\right), 1.4 \mathrm{~mL}$ of $0.00107 \mathrm{M} \mathrm{BTEE}$ and $0.1 \mathrm{~mL}$ test enzyme solution were placed into cuvettes. The enzyme activity was calculated as follows.

$$
\mathrm{A}_{\mathrm{E}}=\frac{\Delta \mathrm{U}_{256} \times(3) \times(\mathrm{Df})}{(0.964) \times(0.10)}
$$

Where:

$\mathrm{A}_{\mathrm{E}} \quad$ : Enzyme activity (Units/mL Enzyme)

$\Delta \mathrm{U}_{256}$ : The change of the absorbance at the wave length $256 \mathrm{~nm}$ per minute

3 : Volume of reaction mixture $(\mathrm{mL})$

Df : Dilution factor

0.964 : Millimolar extinction coefficient of BTEE at $256 \mathrm{~nm}$

0.10 : Volume of test enzyme solution used in assay $(\mathrm{mL})$

\section{Determination of total activity (TA)}

The total activity is defined as the change in the absorbance value per min for the total chymotrypsin extracted from the entire sample of red perch intestine. The total activity was calculated as follows.

$\mathrm{TA}=\frac{\Delta \mathrm{U}_{256} \times(3) \times(\mathrm{Df})}{(0.964) \times(0.10)} \times$ Total volume volume of crude extraction $(2)$

\section{Determination of specific activity (SA)}

Specific activity is defined as the ability of $1 \mathrm{mg}$ enzyme to hydrolysis BTEE in one min at a pH of 7.5 and a temperature of $25^{\circ} \mathrm{C} .0 .1 \mathrm{~mL}$ enzyme solution was added into cuvettes and the change in absorbance

\begin{tabular}{|l|l|l|l|l|l|l|l|}
\hline $\begin{array}{l}\text { Extraction } \\
\text { step }\end{array}$ & \multicolumn{1}{|c|}{$\begin{array}{c}\mathrm{TV} \\
(\mathrm{mL})\end{array}$} & $\begin{array}{c}\mathrm{AE} \\
(\mathrm{Unit} / \mathrm{mL})\end{array}$ & $\begin{array}{c}\mathrm{TA} \\
(\text { Unit })\end{array}$ & $\begin{array}{c}\mathrm{Cp} \\
(\mu \mathrm{g} / \mathrm{mL})\end{array}$ & $\begin{array}{c}\mathrm{SA} \\
(\text { Unit/mg })\end{array}$ & $\begin{array}{c}\mathrm{PF} \\
(-)\end{array}$ & $\begin{array}{c}\mathrm{RY} \\
(\%)\end{array}$ \\
\hline $\begin{array}{l}\text { After Homog- } \\
\text { enizing }\end{array}$ & 183 & 0.80 & 146.40 & 4486.20 & 0.18 & - & - \\
\hline $\begin{array}{l}\text { AfterCentri- } \\
\text { fuging }\end{array}$ & 144 & 0.94 & 135.36 & 1975.80 & 0.48 & 2.69 & 92.70 \\
\hline AfterDilution & & & & & & & 100.00 \\
\hline $\begin{array}{l}\text { and pH } \\
\text { adjustment }\end{array}$ & 288 & 0.47 & 135.36 & 987.90 & 0.48 & - & \\
\hline
\end{tabular}

*Sample size: $50 \mathrm{~g}$

Table 3: Crude protein extraction parameters.

\begin{tabular}{|l|l|}
\hline Parameter & Purified chymotrypsin \\
\hline$A_{E}$ (Unit/mL) & $0.22 \pm 0.01$ \\
\hline TA (Unit) & $1.10 \pm 0.05$ \\
\hline Cp $(\mu \mathrm{g} / \mathrm{mL})$ & $41.64 \pm 1.16$ \\
\hline SA (Unit/mg) & $5.31 \pm 0.19$ \\
\hline PF $(-)$ & $11.10 \pm 0.39$ \\
\hline RY $(\%)$ & $46.72 \pm 2.23$ \\
\hline
\end{tabular}

*Sample size: $5 \mathrm{~mL}$

Table 4: Extraction parameters after ammonium sulphate precipitation. was measured at $256 \mathrm{~nm}$ every half minute for 5 minutes. The specific activity was calculated using the following equation.

$$
\mathrm{S}_{\mathrm{A}}=\frac{\text { Units } / \mathrm{mLEnzyme}}{\mathrm{mg} \text { protein } / \mathrm{mL} \text { Enzyme }}
$$

Where:

$S_{A}$ : Specific activity (Units/mg Protein)

\section{Determination of purification fold (PF)}

Purification fold is used to evaluate the increase in purity of the enzyme after the purification step. It was calculated using the following equation:

$$
\mathrm{PF}=\frac{\text { Units } / \mathrm{mg} \text { Purified protein }}{\text { Units } / \mathrm{mg} \text { Crude protein }}
$$

\section{Determination of recovery yield (RY)}

Recovery yield is defined as the ratio of total refined enzyme activity and total crude enzyme activity. Recovery represents the chymotrypsin activity remaining in the purification process. When combined with specific activity, it can show the effectiveness of a purification method.

$$
\mathrm{RY}=\frac{\text { Units } / \mathrm{mL} \text { Purified protein }}{\text { Units } / \mathrm{mL} \text { Crude protein }} \times 100 \%
$$

\section{Statistical analysis}

The data for solution volume protein concentration and activity
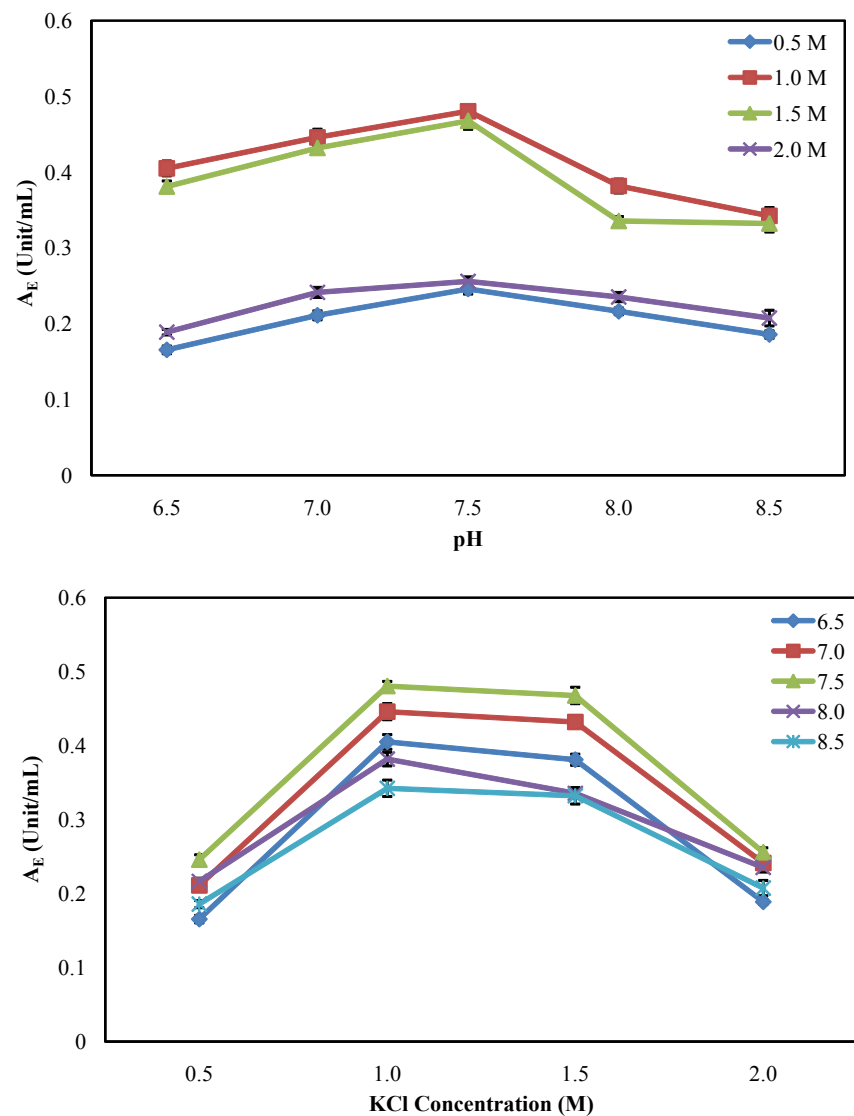

Figure 3: Effects of $\mathrm{pH}$ and $\mathrm{KCl}$ concentration on the enzyme activity. 

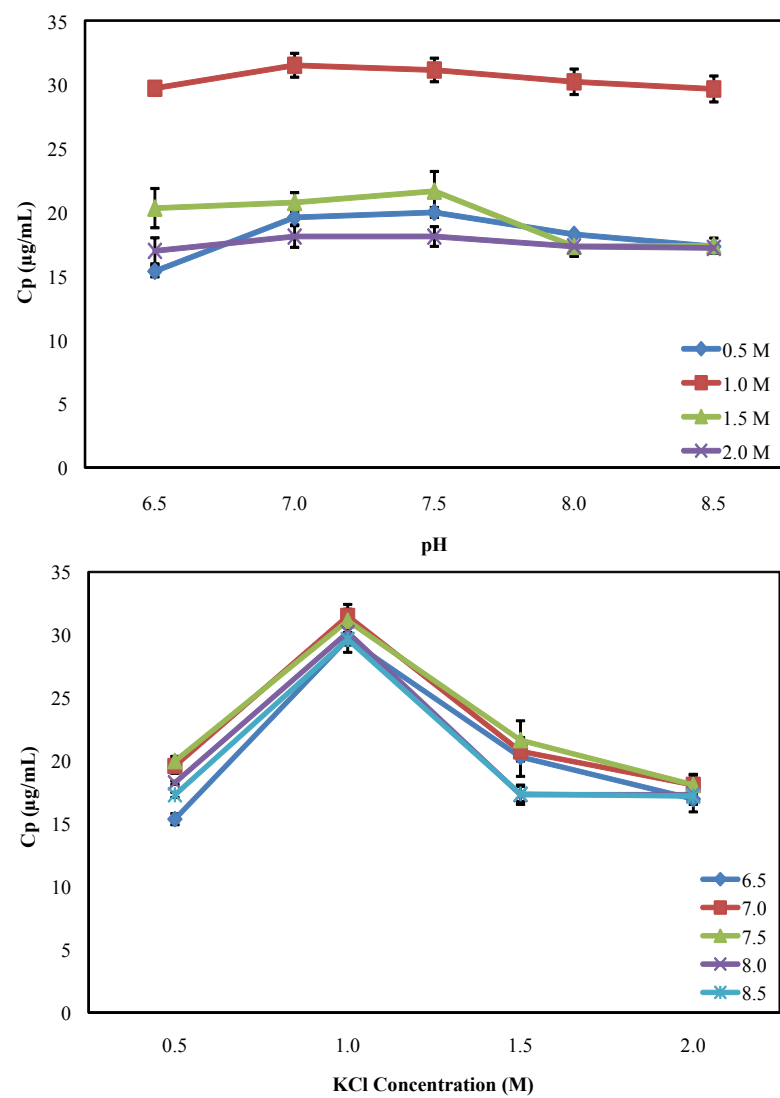

Figure 4: Effects of $\mathrm{pH}$ and $\mathrm{KCl}$ concentration on the protein concentration.

were collected and total activity, recovery yield, specific activity and standard errors were calculated. The $\alpha$-level was chosen as 0.05 . All the statistical analysis of data was conducted using Minitab statistics software (Ver 15.1.10, Minitab Inc) to examine the coefficient data with a two-way analysis of variance (ANOVA) to determine the significant effects of single and two parameters on the results.

\section{Results}

\section{Crude extraction}

Crude protein was extracted from the intestine $(50 \mathrm{~g})$ of red perch and the total volume (TV) was measured after homogenization, centrifugation and dilution. The enzyme activity $\left(A_{E}\right)$, total activity (TA), specific activity (SA), protein concentration (Cp), purification fold (PF) and recovery yield (RY) were determined as shown in Table 3. After centrifugation, the TV, TA and Cp decreased from 183 to $144 \mathrm{~mL}$ (21.32\%), from 146.40 to $135.36 \mathrm{U}$ (7.54\%) and from 4486.2 to 1975.8 $\mu \mathrm{g} / \mathrm{mL}$ (55.96\%), while the $\mathrm{A}_{\mathrm{E}}$ and SA increased from 0.80 to $0.94 \mathrm{U} / \mathrm{mL}$ (17.50\%) and from 0.18 to $0.48 \mathrm{U} / \mathrm{mg}$ (169.1\%), respectively. The purification fold and the recovery yield were 2.69 and $92.7 \%$, respectively.

\section{Ammonium sulphate extraction}

The crude extract was purified using the ammonium sulphate precipitation method. The $A_{\mathrm{E}}, \mathrm{TA}, \mathrm{Cp}, \mathrm{SA}, \mathrm{PF}$ and $\mathrm{RY}$ were determined (Table 4). The $A_{E}$, TA and $C p$ values of the purified enzyme were lower than those of the crude enzyme. The $A_{E}$, TA and $\mathrm{Cp}$ decreased from 0.47 to $0.22 \mathrm{Unit} / \mathrm{mL}$ (53.3\%), from 2.37 to $1.10 \mathrm{Unit} / \mathrm{mL}$ (53.3\%) and from 987.90 to $41.64 \mu \mathrm{g} / \mathrm{mL}$ (95.8\%), respectively. On the other hand, the SA and PF of purified enzyme were much higher than those of
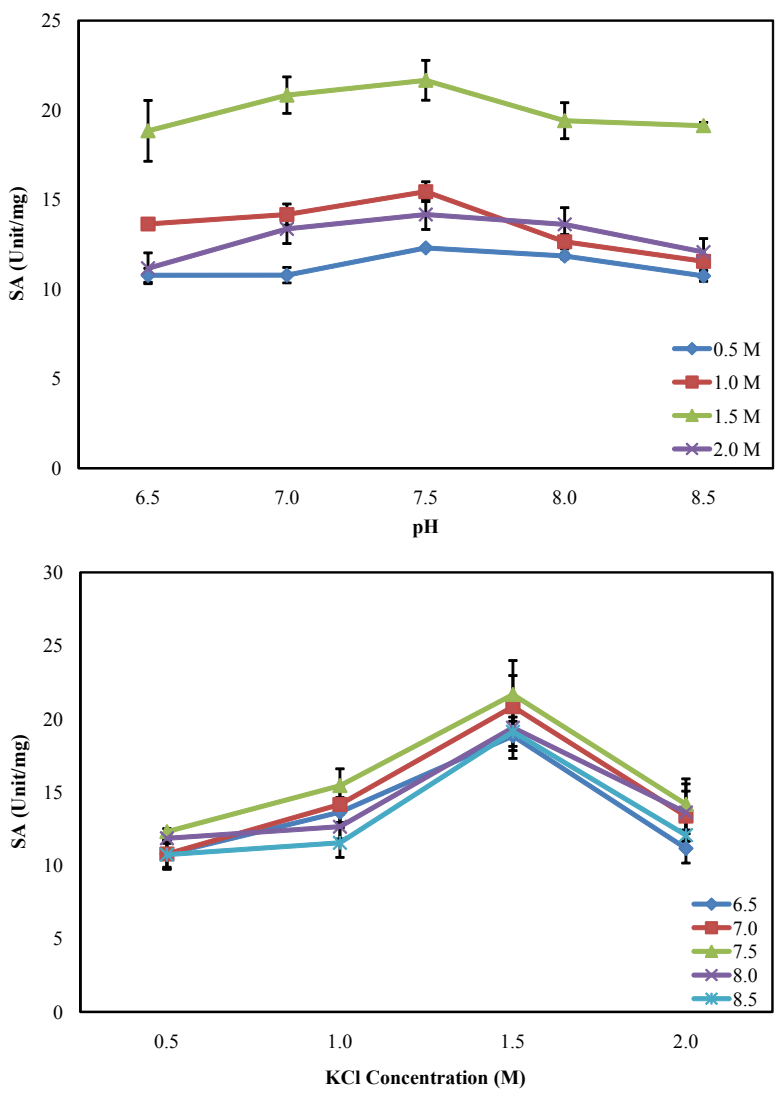

Figure 5: Effects of $\mathrm{pH}$ and $\mathrm{KCl}$ concentration on the specific activity.

crude enzyme. The SA increased from 0.48 to $5.31 \mathrm{Unit} / \mathrm{mg}$ (1012\%) and the PF increased from 2.69 to 11.1 (313.64\%). The final yield was $46.72 \%$.

\section{Reverse micelles extraction}

The effects of salt concentration and $\mathrm{pH}$ on the backward extraction parameters $\left(A_{E}, C p, S A, P F\right.$ and $\left.R Y\right)$ were studied. Four levels of $\mathrm{KCl}$ salt concentrations $(0.5,1.0,1.5$ and $2.0 \mathrm{M})$ and five levels of $\mathrm{pH}$ $(6.5,7.0,7.5,8.0$ and 8.5$)$ were investigated. The results are shown in Figures 3-7. The analysis of variance performed on the data (Table 5) indicated that salt concentration and $\mathrm{pH}$ were highly significant at the 0.0001 level. The interaction between the salt concentration and $\mathrm{pH}$ was highly significant at the 0.0001 level. The highest values for the backward extraction parameters are shown in Table 6.

The volumes for water phase and organic phase remained constant regardless of the $\mathrm{pH}$ level and $\mathrm{KCl}$ concentration used. The TV was 11.5 $\mathrm{mL}$ and the $\mathrm{VR}$ was 0.77 . The $\mathrm{A}_{\mathrm{E}}$ increased initially when the $\mathrm{pH}$ and $\mathrm{KCl}$ were increased and then decreased with further increases in $\mathrm{pH}$ and $\mathrm{KCl}$ concentration (Figure 3 ). The maximum $\mathrm{A}_{\mathrm{E}}$ value (0.48 unit/ $\mathrm{mL}$ ) was observed at $\mathrm{pH} 7.5$ and $\mathrm{KCl}$ concentration of $1.0 \mathrm{M}$. The $\mathrm{Cp}$ showed similar trend with the maximum value $(31.13 \mu \mathrm{g} / \mathrm{mL})$ observed at $\mathrm{pH} 7.5$ and $\mathrm{KCl}$ concentration of $1.0 \mathrm{M}$ (Figure 4). The SA and PF showed similar behaviours with maximum values $(21.67 \mathrm{unit} / \mathrm{mg}$ and 45.23) observed at $\mathrm{pH}$ of 7.5 and $\mathrm{KCl}$ concentration of $1.5 \mathrm{M}$ (Figures 5 and 6). The RY had a maximum value (102.24\%) at $\mathrm{pH}$ of 7.5 and $\mathrm{KCl}$ concentration of $1.0 \mathrm{M}$. These results showed that the optimum condition for the backward extraction step of chymotrypsin is at a $\mathrm{pH}$ of 7.5 and $\mathrm{KCl}$ concentration of $1.0 \mathrm{M}$ and $1.5 \mathrm{M}$. 



Figure 6: Effects of $\mathrm{pH}$ and $\mathrm{KCl}$ concentrations on the purification fold.

\section{Alcohol effect}

In order to determine the effect of alcohol in the backward extraction step, an experiment was carried out at the optimal conditions for forward (AOT $20 \mathrm{mM}$, and $\mathrm{pH} 7.0$ ) and backward (KCl $1.0 \mathrm{M}$ and $\mathrm{pH}$ 7.5) extraction in which isobutyl alcohol was added in the backward extraction step. Another experiment without alcohol was used as a control. The TV, AE, TA, Cp, PF and RY obtained form both experiments are shown in Table 7. When alcohol was added in the backward extraction step, the TV, $\mathrm{A}_{\mathrm{E}}$, TA, Cp, SA, PF and RY increased from 4.4 to $5.0 \mathrm{~mL}(13.6 \%)$, from 0.11 to $0.48 \mathrm{Unit} / \mathrm{mL}$. (336.4\%), from 0.54 to $2.39 \mathrm{U}$ (342.6\%), from 17.60 to $31.87 \mu \mathrm{g} / \mathrm{mL}$ (81.1\%), from 6.08 to 14.98 Unit/mg (146.4\%), from 12.70 to 31.27 (146.2\%) and from $22.62 \%$ to $100.85 \%$ (345.8\%), respectively

\section{Comparing RM with AS}

The reverse micelles (RM) method was compared to the ammonium sulphate (AS) method on the basis of their AE, TA Cp, SA, PF and RY (Table 8). The value of extraction parameters obtained with RM were much higher than those obtained with AS. The $A_{E}, T A$, and RY obtained with RM were 2 fold higher than those obtained with the AS method, while the SA and PF were 3 fold higher than those obtained with AS.

\section{Discussion}

\section{Extraction profiles}

After homogenization and centrifugation, the $A_{E}, T A, C p$ and RY
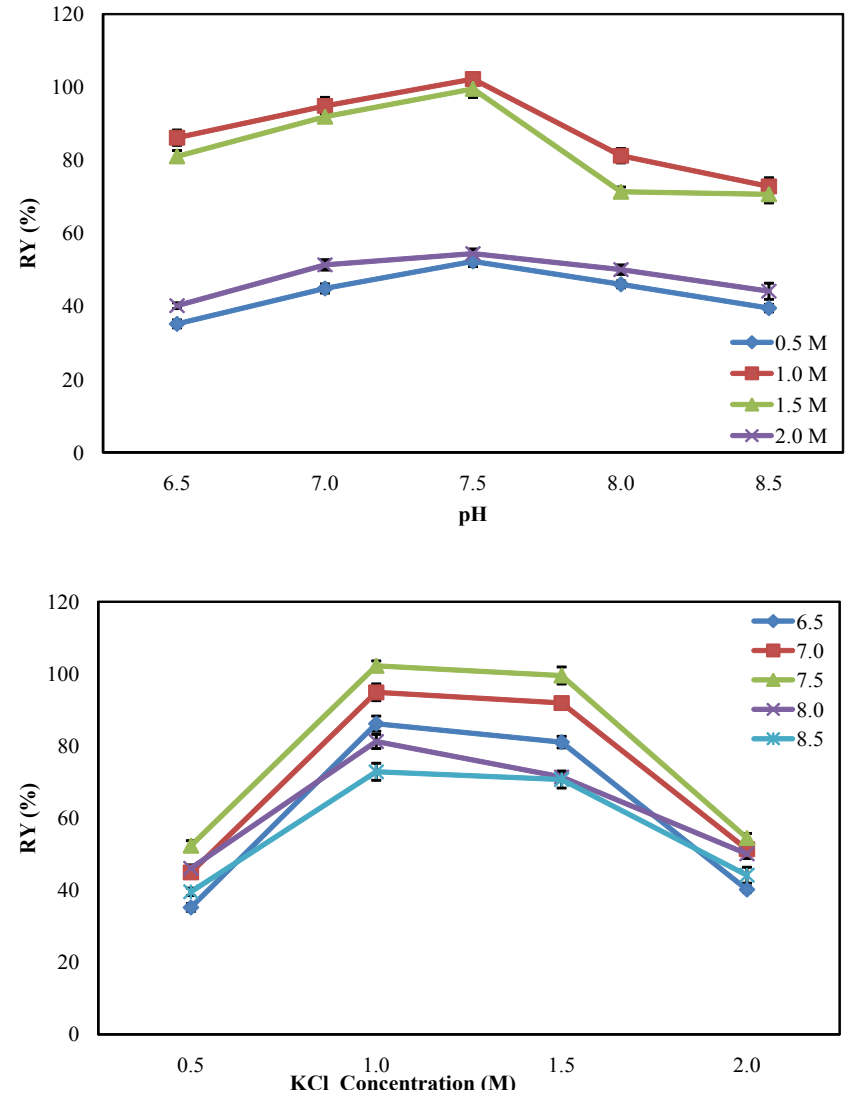

Figure 7: Effects of $\mathrm{pH}$ and $\mathrm{KCl}$ concentration on the recovery yield.

\begin{tabular}{|c|c|c|c|c|c|c|}
\hline Parameters & Source & DF & SS & MS & $\mathrm{F}$ & $P$ \\
\hline \multirow[t]{5}{*}{$A_{E}$} & Total & 107 & 0.74882 & & & \\
\hline & $\mathrm{pH}$ & 5 & 0.1533 & 0.03066 & 52.87 & 0.0001 \\
\hline & AOT & 5 & 0.50872 & 0.10174 & 175.43 & 0.0001 \\
\hline & $\mathrm{pH}-\mathrm{AOT}$ & 25 & 0.04504 & 0.0018 & 3.11 & 0.0001 \\
\hline & Error & 72 & 0.04176 & 0.00058 & & \\
\hline \multirow[t]{5}{*}{$\mathrm{Cp}$} & Total & 107 & 2496.22 & & & \\
\hline & $\mathrm{pH}$ & 5 & 299.76 & 59.952 & 72.25 & 0.0001 \\
\hline & AOT & 5 & 1930.26 & 386.051 & 465.26 & 0.0001 \\
\hline & $\mathrm{pH}-\mathrm{AOT}$ & 25 & 206.46 & 8.258 & 9.95 & 0.0001 \\
\hline & Error & 72 & 59.74 & 0.83 & & \\
\hline \multirow[t]{5}{*}{ SA } & Total & 107 & 340.295 & & & \\
\hline & $\mathrm{pH}$ & 5 & 105.573 & 21.1027 & 19.04 & 0.0001 \\
\hline & AOT & 5 & 133.499 & 26.6998 & 24.09 & 0.0001 \\
\hline & $\mathrm{pH}-\mathrm{AOT}$ & 25 & 21.482 & 0.8593 & 0.78 & 0.758 \\
\hline & Error & 72 & 79.801 & 1.1083 & & \\
\hline \multirow[t]{5}{*}{ PF } & Total & 59 & 3268.06 & & & \\
\hline & $\mathrm{pH}$ & 4 & 213.18 & 53.294 & 21.89 & 0.0001 \\
\hline & AOT & 3 & 2871.22 & 957.074 & 393.15 & 0.0001 \\
\hline & $\mathrm{pH}-\mathrm{AOT}$ & 12 & 86.28 & 7.19 & 2.95 & 0.0050 \\
\hline & Error & 40 & 97.38 & 2.434 & & \\
\hline \multirow[t]{5}{*}{ RY } & Total & 59 & 28097.9 & & & \\
\hline & $\mathrm{pH}$ & 4 & 3278 & 819.49 & 291.02 & 0.0001 \\
\hline & AOT & 3 & 23562.5 & 7854.18 & 2789.23 & 0.0001 \\
\hline & $\mathrm{pH}-\mathrm{AOT}$ & 12 & 1144.7 & 95.39 & 33.88 & 0.0001 \\
\hline & Error & 40 & 112.6 & 2.82 & & \\
\hline
\end{tabular}

$\mathrm{pH}=$ Mean effect of $\mathrm{pH}$

AOT $=$ Mean effect of AOT

$\mathrm{pH}-\mathrm{AOT}=$ interaction between $\mathrm{pH}$ and $\mathrm{AOT}$

Table 5: Analysis of variance for the various parameters. 


\begin{tabular}{|l|l|l|l|}
\hline Parameters & $\mathrm{pH}$ & $\mathrm{KCl}$ & Optimum values \\
\hline $\mathrm{A}_{\mathrm{E}}($ Unit/mL $)$ & 7.5 & $1.0 \mathrm{M}$ & $0.48 \pm 0.06$ \\
\hline $\mathrm{Cp}(\mu \mathrm{g} / \mathrm{mL})$ & 7.5 & $1.0 \mathrm{M}$ & $31.13 \pm 0.93$ \\
\hline $\mathrm{SA}($ Unit/mg $)$ & 7.5 & $1.5 \mathrm{M}$ & $21.67 \pm 1.11$ \\
\hline $\mathrm{PF}(-)$ & 7.5 & $1.5 \mathrm{M}$ & $45.23 \pm 2.32$ \\
\hline RY $(\%)$ & 7.5 & $1.0 \mathrm{M}$ & $102.24 \pm 1.35$ \\
\hline
\end{tabular}

*Sample size: $5 \mathrm{~mL}$

Table 6: The optimum values of chymotrypsin purification parameters.

\begin{tabular}{|l|l|l|}
\hline Parameters & Without alcohol & With alcohol \\
\hline $\mathrm{A}_{\mathrm{E}}$ (Unit/mL) & $0.11 \pm 0.01$ & $0.48 \pm 0.01$ \\
\hline $\mathrm{TA}($ Unit) & $0.54 \pm 0.05$ & $2.39 \pm 0.05$ \\
\hline $\mathrm{Cp}(\mu \mathrm{g} / \mathrm{mL})$ & $17.60 \pm 5.48$ & $31.87 \pm 1.31$ \\
\hline $\mathrm{SA}($ Unit/mg) & $6.08 \pm 0.19$ & $14.98 \pm 0.49$ \\
\hline $\mathrm{PF}$ & $12.70 \pm 0.39$ & $31.27 \pm 1.02$ \\
\hline RY $(\%)$ & $22.62 \pm 2.23$ & $100.85 \pm 2.23$ \\
\hline
\end{tabular}

Forward extraction: AOT concentration $20 \mathrm{mM}$, pH7.0

Backward extraction: $\mathrm{KCl}$ concentration $1.5 \mathrm{M}$, pH7.5

*Sample size: $5 \mathrm{~mL}$

Table 7: Effect of alcohol addition on chymotrypsin purification parameters.

\begin{tabular}{|l|l|l|}
\hline Parameters & AS & RM \\
\hline$A_{E}$ (Unit/mL) & $0.22 \pm 0.01$ & $0.48 \pm 0.01$ \\
\hline TA (Unit) & $1.10 \pm 0.05$ & $2.39 \pm 0.05$ \\
\hline Cp $(\mu \mathrm{g} / \mathrm{mL})$ & $41.64 \pm 5.48$ & $31.87 \pm 1.31$ \\
\hline SA (Unit/mg) & $5.31 \pm 0.19$ & $14.98 \pm 0.49$ \\
\hline PF & $11.08 \pm 0.39$ & $31.27 \pm 1.02$ \\
\hline RY $(\%)$ & $46.72 \pm 2.23$ & $100.85 \pm 2.23$ \\
\hline
\end{tabular}

Forward extraction: AOT concentration $20 \mathrm{mM}$, pH7.0

Backward extraction: $\mathrm{KCl}$ concentration $1.5 \mathrm{M}$, pH7.5

*Sample size: $5 \mathrm{~mL}$

Table 8: Optimum values of the AS and RM purification parameters.

decreased while the SA and PF increased which indicated that a portion of chymotrypsin was lost during the crude extraction process but the remaining portion was concentrated during the extraction.

\section{Reverse micelles method}

During the backward extraction step, salt was required to break the reverse micelles structure in the organic phase to release chymotrypsin into the aqueous phase. However, high salt concentrations will denaturate proteins [21]. The $\mathrm{pH}$ on the other hand affects the net charge of protein molecules and the electrostatic interaction force between the chymotrypsin and the surfactant. This in turn influences the extraction efficiency of the process [9,21-23]. In the present study, the effects of $\mathrm{pH}(6.5,7.0,7.5,8.0$ and 8.5) and $\mathrm{KCl}$ concentration $(0.5,1.0,1.5$, and $2.0 \mathrm{M}$ ) were investigated in order to determine the optimum conditions for the backward extraction step.

During the backward extraction step, the volumes for the organic and aqueous phases remained constant regardless of the $\mathrm{pH}$ and $\mathrm{KCl}$ concentration used. Thus, the total volume for each of the five $\mathrm{pH}$ levels and the four $\mathrm{KCl}$ concentrations was $11.5 \mathrm{~mL}$ and the $\mathrm{VR}$ of the two phases remained constant at 0.77 . Several researchers reported similar results $[9,12,21,22,24]$.

It has been reported that changes in the structure of proteins and the low rate of extraction are the main problems with the backward extraction step. Changing the $\mathrm{pH}$ and the concentration of salt in the aqueous phase are the most common methods applied to improve $A_{E}$, $\mathrm{Cp}, \mathrm{SA}, \mathrm{PF}$ and RY of the backward extraction [24-27]. In the study, $\mathrm{A}_{\mathrm{E}}$,
$\mathrm{Cp}, \mathrm{SA}, \mathrm{PF}$ and $\mathrm{RY}$ reached their maximum values at $\mathrm{pH} 7.5$ and $\mathrm{KCl}$ concentration of $1.5 \mathrm{M}$.

Goto et al. [12] reported that during the backward extraction of chymotrypsin using $200 \mathrm{mM}$ AOT concentration, an increase in $A_{E}$ (from 1 to $6 \mathrm{Unit} / \mathrm{mL}$ ) was observed when the $\mathrm{pH}$ was increased from 4.0 to 7.5 which was followed by a decrease (to $0.5 \mathrm{Unit} / \mathrm{mL}$ ) with further increases in the $\mathrm{pH}$ (to 11.0). When the positive net charge on the chymotrypsin surface decreased, the electrostatic interaction between the protein and the negative AOT molecular head became weaker and chymotrypsin was released into the aqueous phase [12].

When the $\mathrm{pH}$ of the aqueous phase approaches the isoelectric point $(p I)$ of proteins, the $\mathrm{Cp}$ increases because of the electrostatic interaction between the protein and AOT reverse micelles is weakened and more protein molecules are released from the reverse micelles into the aqueous phase. However, further increases in the $\mathrm{pH}$ result in decreasing $\mathrm{Cp}$ because of protein denaturation. Ono et al. [21] reported that when the $\mathrm{pH}$ was increased during the extraction of haemoglobin using dioleyl phosphoric acid (DOLPA), the backward extraction rate dramatically increased reaching $90 \%$ at a $\mathrm{pH}$ of 8.0 and then declined with further increases in the $\mathrm{pH}$. Similar results had been observed by Goto et al. [12].

$\mathrm{RY}$ is one of the most important parameters used in evaluating the extraction process. Generally, the RY of the backward extraction is relatively lower than the forward extraction due to the strong interaction between the protein and reverse micelles $[9,11,12,21,23,24,28]$. Several researchers reported similar effects of $\mathrm{pH}$ in the backward extraction on RY $[12,21,23,28]$. Hebbar et al. [28] reported that during the extraction of bromelain from pineapple waste, RY increased from 68 to $100 \%$ when the aqueous phase $\mathrm{pH}$ was increased from 3.9 to 4.2 and then decreased with further increases in $\mathrm{pH}$. Goto et al. [12] reported a $100 \%$ $\mathrm{RY}$ of chymotrypsin using AOT-DOLPA at $\mathrm{pH}$ of 7.0.The reason that RY was over $100 \%$ in this study could be due to the presence of impurities with chymotrypsin.

Chang et al. [23] stated that the $\mathrm{KCl}$ concentration had significant effects on the radius of reverse micelles and changing the salt concentration affected $A_{E}, C p, S A, P F$ and $R Y$. They reported that when $\mathrm{KCl}$ concentration was increased from 0.2 to $0.8 \mathrm{M}$, the radius of reverse micelles decreased from 62 to $41 \AA$ which in turn decreased protein solubility and was responsible for the release of protein to the aqueous phase. High salt concentration resulted in unstable reverse micelle structures and led to increases in the $\mathrm{A}_{\mathrm{E}}, \mathrm{Cp}, \mathrm{SA}, \mathrm{PF}$ and RY. Hebbar et al. [28] reported that during the backward extraction step of extracting bromelain from pineapple waste, the $\mathrm{A}_{\mathrm{E}}$ increased when the $\mathrm{KBr}$ concentration was increased from 0.25 to $0.50 \mathrm{M}$ and then decreased when the $\mathrm{KBr}$ concentration further increased from 0.50 to $0.75 \mathrm{M}$. Hatton et al. [29] and Dekker et al. [25] also found that a high ionic strength in the aqueous phase was not good for protein extraction in the backward extraction step. Hong et al. [24] extracted BSA, carbon anhydrase and $\beta$-lactoglubulin from AOT reverse micelles using low ionic strength conditions in the aqueous phase $(0.1 \mathrm{M} \mathrm{KCl})$ and found that high ionic strength could result in protein denaturation. High ionic strength was considered to be a salt concentration $>1 \mathrm{M}$. High salt concentrations can destabilize reverse micelles and release target proteins back to the aqueous phase and as such increase SA. Hebbar et al. [28] reported that when the aqueous phase $\mathrm{pH}$ was increased from 3.9 to 4.2 during the backward extraction of bromelain from pineapple waste, SA and PF increased from 22.6 to $56.15 \mathrm{CDU} / \mathrm{mg}$ and from 2.1 to 5.3 , respectively. 
Then, they decreased to $25 \mathrm{CDU} / \mathrm{mg}$ and 2.4 when the $\mathrm{pH}$ was further increased to 4.5 . They also reported that when the $\mathrm{KBr}$ concentration increased from 0.25 to $0.50 \mathrm{M}$, SA increased from 20 to $56 \mathrm{CDU} / \mathrm{mg}$ and then decreased to $23 \mathrm{CDU} / \mathrm{mg}$ and $\mathrm{PF}$ increased from 2.1 to 5.6 and then decreased to 2.4 when the $\mathrm{KBr}$ concentration was further increased to $0.75 \mathrm{M}$. Hu and Gulari [9] reported a RY of $67.6 \%$ during the extraction of $\alpha$-chymotrypsin using sodium bis (2-ethyIhexyI) phosphate (NaDEHP) with a $\mathrm{CaCl}_{2}$ concentration of $0.1 \mathrm{M}$. Hentsh et al. [11] reported a 100\% RY during the backward extraction of chymotrypsin using $1.0 \mathrm{M} \mathrm{KCl}$ at $\mathrm{pH}$ of 8.0. In this study, SA and PF decreased when $\mathrm{KCl}$ concentration increased above $1.5 \mathrm{M}$, a higher concentration than that reported by others.

The optimum $\mathrm{pH}$ and $\mathrm{KCl}$ concentration that gave the highest $\mathrm{A}_{\mathrm{E}}$, $\mathrm{Cp}, \mathrm{SA}, \mathrm{PF}$ and RY for the backward extraction are shown in Table 4. The highest $\mathrm{A}_{\mathrm{E}}, \mathrm{Cp}$ and $\mathrm{RY}$ were reached at the $\mathrm{pH} 7.5$ and $\mathrm{KCl}$ concentration of $1.0 \mathrm{M}$ while the highest SA and PF were reached at the $\mathrm{pH} 7.5$ and $\mathrm{KCl}$ of concentration 1.5 M. Since RY has been considered the most important parameter in evaluation of the extraction process, $\mathrm{pH}$ of 7.5 and $\mathrm{KCl}$ concentration of $1.0 \mathrm{M}$ were chosen as the optimum backward extraction conditions. The optimal $\mathrm{pH}$ applied in the backward extractions ( $\mathrm{pH}$ 7.5) is higher than that in forward extraction ( $\mathrm{pH}$ 7.0). Ono et al. [21] reported $\mathrm{pH} 6.5$ and 8.0 for the forward and backward extraction during the extraction steps of haemoglobin using DOLPA. Hentsch et al. [11] used pH 5.0 and 8.0 for forward and backward extraction steps during the extraction of chymotrypsin using AOT. Goto et al. [12] found the optimal $\mathrm{pH}$ conditions for extraction of chymotrypsin using AOT-DOLPA mixed reverse micelle system to be $\mathrm{pH} 6.8$ for forward extraction and $\mathrm{pH} 7.0$ for backward extraction.

\section{Effect of alcohol on backward extraction}

Adding alcohol in the backward extraction step increased TV, A, TA, Cp, SA, PF and RY. Hu and Gulari [9], Goto et al. [12], Ono et al. [21], Paradkar and Dordick [22] and Hong et al. [24] reported that a clear phase was quickly obtained in the presence of alcohol after stopping the stirring process and with the addition of $10-20 \%(\mathrm{v} / \mathrm{v})$ alcohol in the backward extraction step, the protein transfer from reverse micelles was 10 times faster than in the absence of alcohol. Paradker and Dordick (1993) added 10\%(v/v) ethyl acetate in the backward extraction step and noticed significant increases in $A_{E}$, TA and RY. Goto et al. [12] reported that without the addition of alcohol, 24 hours were required to obtain equilibrium in the back-extraction step and the extraction time was reduced to less than 2 hours by adding $10 \%$ (v/v) isobutyl alcohol. Hong et al (2000) reported that adding 10-15\% isopropanol in the backward extraction step resulted in 100\% extraction of pepsin and $70 \%$ extraction of chymotrypsin. Hu and Gulari [9] reported that only $10-20 \%$ RY were obtained using the NaDEHP reverse micelle system without the addition of alcohol in the backward extraction but $98 \%$ of active cytochrome-c and $67 \%$ of active chymotrypsin were recovered from the aqueous phase in the presence of alcohol.

Goto et al. [12] studied the effect of alcohol type on the RY and relative activity of recovered chymotrypsin. Their results showed that the RY of the backward extraction with isopropyl alcohol, isobutyl alcohol, isoamyl alcohol, n-hexyl alcohol, n-octyl alcohol, n-decanol and oleyl alcohol were $93.8 \%, 97.1 \%, 90.7 \%, 84.5 \%, 67.4 \%$, 59.9\%and $37.1 \%$, respectively. The relative activity (recovered specific activity/original specific activity) for recovered chymotrypsin in the backward extraction using isopropyl alcohol, isobutyl alcohol, isoamyl alcohol, n-hexyl alcohol, n-octyl alcohol, n-decanol and oleyl alcohol were 0.03, 1.00, $0.74,0.68,0.24,0.10$ and 0.55 respectively.
Ono et al. [21] studied the effect of alcohol type and concentration in the backward extraction step using methanol, ethanol, isopropyl alcohol (IPA) and n-propyl alcohol (nPA) at concentrations of $0-30 \%$ $(\mathrm{v} / \mathrm{v})$. When the IPA and nPA were added in the back-extraction step, the hemoglobin recovery rate increased significantly from 0 to $60 \%$ when alcohol concentration was increased from 5 to $10 \%(\mathrm{v} / \mathrm{v})$ and then decreased with further increases in the alcohol concentration. The hemoglobin recovery rate dramatically increased from 0 to $70 \%(\mathrm{v} / \mathrm{v})$ when the ethanol concentration was increased from 10 to $15 \%(\mathrm{v} / \mathrm{v})$ and then decreased when the concentration was further increased. The recovered hemoglobin rate dramatically increased from 0 to $70 \%(\mathrm{v} / \mathrm{v})$ when the methanol concentration in the back extraction was increased from 20 to $30 \%(\mathrm{v} / \mathrm{v})$. Alcohol can reduce the interfacial resistance for the reverse micelles because it promotes the fusion/fission of reverse micelles which destabilizes the structure.

\section{Conclusions}

Changing the $\mathrm{pH}$ from 6.5 to 8.5 and the $\mathrm{KCl}$ concentration from 0.5 to $2.0 \mathrm{M}$ during backward extraction step (with addition of alcohol) had no effects on the total volume (TV) or the volume ratio (VR). The TV for all samples was $6.5 \mathrm{~mL}$ and the VR was 0.77 . The reverse micelles emulsion structure was destroyed in the presence of alcohol Increasing the $\mathrm{pH}$ from 6.5 to 7.5 increased the enzyme activity $\left(\mathrm{A}_{\mathrm{F}}\right)$ by up to $47.06 \%$, protein concentration (Cp) by up to $30.0 \%$, specific activity (SA) by up to $27.0 \%$, purification factor (PF) by up to $26.9 \%$ and recovery yield (RY) by up to $18.47 \%$ and they all then declined with further increases in the $\mathrm{pH}$. Similarly, increases in the $\mathrm{KCl}$ concentration from 0.5 to $1.0 \mathrm{M}$ increased $\mathrm{A}_{\mathrm{E}}$ by up to $192.9 \%$, Cp by up to $93.2 \%$ and RY by up to $50.97 \%$ and they all then decreased with further increases in the $\mathrm{KCl}$ concentration. SA and PF continued to increase up to $93.3 \%$ when the $\mathrm{KCl}$ concentration increases from 0.5 to $1.5 \mathrm{M}$ and then decreased with further increases in the $\mathrm{KCl}$ concentration. The decreases in $A_{E}, C p, S A, P F$ and $R Y$ were due to the denaturation of protein under a relatively high $\mathrm{pH}$ and the ionic strength caused by high $\mathrm{pH}$ and $\mathrm{KCl}$ concentration in the backward extraction step. The highest $A_{E}, C p$ and $\mathrm{RY}$ were achieved with $\mathrm{pH}$ of 7.5 and $1.0 \mathrm{M} \mathrm{KCl}$ concentration. The highest $\mathrm{SA}$ and $\mathrm{PF}$ were achieved with $\mathrm{pH}$ of 7.5 and $1.5 \mathrm{M} \mathrm{KCl}$ concentration. The optimal conditions for the backward extraction step was $\mathrm{pH} 7.5, \mathrm{KCl}$ concentration 1.0 M. Addition of alcohol in the backward extraction step increased TV by $13.6 \%$, $\mathrm{A}_{\mathrm{E}}$ by $336.4 \%$, TA by $342.6 \%, \mathrm{Cp}$ by $81.1 \%$, SA by $146.4 \%$, PF by $146.2 \%$ and RY by $345.8 \%$ because alcohol reduced the interfacial resistance for the reverse micelles. The values of $A_{E}$, TA, SA, PF and RY obtained with reverse micelles methods were much higher ( 2.3 fold) than those obtained with the AS method.

\section{Acknowledgements}

The project was funded by the Natural Sciences and Engineering Research Council (NSERC) of Canada through a Strategic Grant.

\section{References}

1. PNPPRC (1993) Pollution prevention opportunities in the fish processing industry, Pacific Northwest Pollution Prevention Research Center, Seattle, Washington, USA.

2. AMEC (2003) Management of wastes from Atlantic seafood processing operations, National programme of action Atlantic regional team, AMEC Earth \& Environmental Limited, Dartmouth, Nova Scotia, Canada.

3. Bechtel PJ (2003) Properties of different fish processing by-products from pollock, cod and salmon. J Food Process Preserv 27: 101-116.

4. Gumisiriza R, Mashandete AM, Rubindamayugi MST, Kansiime F, Kivaisi AK (2009) Enhancement of anaerobic digestion of Nile perch fish processing wastewater. Afr J Biotechnol. 8: 328-333. 
Citation: Zhou L, Budge SM, Ghaly AE, Brooks MS, Dave D (2012) Extraction of Chymotrypsin from Red Perch (Sebastes marinus) Intestine Using Reverse Micelles: Optimization of the Backward Extraction Step. J Bioprocess Biotechniq 2:120 doi: 10.4172/2155-9821.1000120

5. Byun HG, Park PJ, Sung NJ, Kim SK (2002) Purification and characterization of a serine proteinase from the tuna pyloric caeca. J Food Biochem 26: 479-494.

6. Swatschek D, Schatton W, Kellerman J, Muller WEG, Kreuter J (2002) Marine sponge collagen: isolation, characterization and effects on the skin parameters on $\mathrm{pH}$, moisture and sebum. Eur J Pharm Biopharm 53: 107-113.

7. Kim S, Mendis E (2006) Bioactive compounds from marine processing byproducts-A review. Food Res Int 39: 383-393.

8. Jolivalt C, Minier M, Renon H (1990) Extraction of a-chymotrypsin using reverse micelles. J Colloid Interface Sci 135: 85-96.

9. Hu ZY, Gulari E (1996) Communication to the editor protein extraction using the sodium bis (2-ethylhexyl) phosphate (NaDEHP) reverse micellar system. Biotechnol Bioeng 50: 203-206.

10. Zhou L, Budge SM, Ghaly AE, Brooks MS, Dave D (2011) Extraction, purification and characterization of fish chymotrypsin: A Review. Am J Biochem Biotechnol 7: 104-123.

11. Hentsch M, Menoud P, Steiner L, Flaschel E, Renken A (1992) Optimization of the surfactant (AOT) concentration in a reverse micelle extraction process. Biotechnology Techniques 6: 359-364

12. Goto M, Ishikawa Y, Ono T, Nakashio F, Hatton TA (1998) Extraction and activity of chymotrypsin using AOT-DOLPA mixed reversed micellar systems. Biotechnol Prog 14: 729-734.

13. Chong ASC, Hashim R, Chow-Yang L, Ali AB (2002) Partial characterization and activities of proteases from the digestive tract of discus fish Symphysodon aequifasciata. Aquaculture 203: 321-333.

14. Boeris V, Romanini D, Farruggia B, Pico G (2009) Purification of chymotrypsin from bovine pancreas using precipitation with a strong anionic polyelectrolyte. Process Biochem 44: 588-592.

15. Heu MS, Kim HR Pyeun JH (1995) Comparison of trypsin and chymotrypsin from the viscera of anchovy, Engraulis japonica. Comp Biochem Physiol B Biochem Mol Biol 112: 557-567.

16. Castillo-Yáñez FJ, Pacheco-Aguilar R, Garcia-Carreno FL (2006) Purification and biochemical characterization of chymotrypsin from the viscera of Monterey sardine (Sardinops sagax caeruleus). Food Chemistry 99: 252-259.
17. Kunitz (1948) Crystallization of salt-free chymotrypsinogen and chymotrypsin from solution in dilute ethyl alcohol. J Gen Physiol.

18. Yang F, Su WJ, Lu BJ, Wu T, Sun LC, et al. (2009) Purification and characterization of chymotrypsins from the hepatopancreas of crucian carp (Carassius auratus). Food Chemistry 116: 860-866

19. Olson BJSC Markwell J (2007) Assays for determination of protein concentration. Current Protocols in Protein Science, John Wiley \& Sons, Inc, New Jersey.

20. Chakrabarti R, Rathore RM, Mittal P, Kumar S (2006) Functional changes in digestive enzymes and characterization of proteases of silver carp ( $)$ and bighead carp $(+)$ hybrid, during early ontogeny. Aquaculture 253: 694-702.

21. Ono T, Goto M, Nakashio F, Hatton TA (1996) Extraction behaviour of haemoglobin using reverse micelles by dioleyl phosphoric acid. Biotechnol Prog 12 793-800.

22. Paradkar VM, Dordick JS (1994) Mechanism of extraction of chymotrypsin at very low concentrations of Aerosol OT in the absence of reverse micelles. Biotechnol Bioeng 43: 529-540.

23. Chang Q, Liu H, Chen J (1994) Extraction of lysozyme, $\alpha$-chymotrypsin and pepsin into reverse micelles formed using an anionic surfactant, isooctane and water. Enzyme Microb Technol 16: 970-973.

24. HongDP, Lee SS, Kuboi R (2000) Conformational transition and mass transfer in extraction of proteins by AOT-alcohol-isooctane reverse micellar systems. $J$ Chromatogr B Biomed Sci Appl 743: 203-213.

25. Dekker M, Van't Riet K, Van der Pol JJ, Baltussen JWA, Hilhorst R, et al. (1991) Effect of temperature on the reversed micellar extraction of enzymes. Chem Eng J 46: B69-B74.

26. Nishiki T, Sato I, Muto A, Kataoka T (1998) Mass transfer characterization in forward and back extractions of lysozyme by AOT-isooctane reverse micelles across a flat liquid-liquid interface. Biochem Eng J 1: 91-97.

27. Nishiki T, Nakamura K, Kato D (2000) Forward and backward extraction rates of amino acids in reversed micellar extraction. Biochem Eng J 4: 189-195.

28. Hebbar HU, Sumana B, Raghavarao KSMS (2008) Use of reverse micellar systems for the extraction and purification of bromelain from pineapple wastes. Bioresour Technol 99: 4896-4902.

29. Hatton TA, Scamehorn JF, Harwell JH (Eds.) (1989) Surfactant-based separation processes, Marcel Dekker, New York. 